\title{
Distribution of the ardA family of antirestriction genes on conjugative plasmids
}

\author{
Paul M. Chilley and Brian M. Wilkins
}

Department of Genetics, University of Leicester, Leicester LE1 7RH, UK

\author{
Author for correspondence: Brian M. Wilkins. Tel: +44 116252 3432/3374. Fax: +44 1162525101 .
}

\begin{abstract}
The ardA gene of 11 plasmid Collb-P9 was previously shown to alleviate DNA restriction by type I enzymes and to promote conjugative transmission of the unmodified plasmid to a restricting host. To clarify the ecological role of ardA, its distribution was determined on plasmids from 23 incompatibility groups using hybridization to the coding sequence as an assay. Hybridizing sequences, shown by nucleotide sequencing to have at least $60 \%$ identity with ardA , were detected on plasmids belonging to the I complex (InCB, I1 and K), the F complex (IncFV) and the IncN group. The ardA homologues were found to specify an antirestriction phenotype which was enhanced by genetic derepression of the plasmid transfer system. ardA loci map in plasmid leading regions but show no consistent association with a particular type of origin-oftransfer or a leading region gene of the ssb (single-stranded DNA-binding protein), psiB (plasmid SOS inhibition) and hok (host killing) families. It may be significant that ardA+ plasmids are authentic enterobacterial plasmids and that type I restriction systems are associated historically with members of the Enterobacteriaceae.
\end{abstract}

Keywords: bacterial conjugation, conjugative plasmids, restriction alleviation, type I restriction enzymes

\section{INTRODUCTION}

Bacterial restriction-modification ( $\mathrm{R}-\mathrm{M}$ ) systems consist of a restriction endonuclease plus a matching modification methyltransferase which recognize the same specificity site. Methylation of one or both strands at the recognition site protects the DNA from the cognate restriction enzyme. R-M systems can be divided into three types. Type III systems, which are the least common, cleave DNA on one side of asymmetric specificity sites. Classical type II systems, familiar through the enzymes central to recombinant DNA technology, are comprised of separate methylases and endonucleases that recognize short specificity sites with an axis of rotational symmetry. Type I systems are more complex; the main enzyme is a multisubunit protein active in restriction and modification, the specificity sites are characteristically asymmetric, and DNA cleavage occurs at variable and often considerable distances from the recognition sites (Wilson \& Murray, 1991; Bickle \& Krüger, 1993; Barcus \& Murray, 1995).

\footnotetext{
Abbreviation: R-M, restriction-modification.
}

The EMBL accession numbers for the sequences reported in this paper are Z34467 and Z34468.
Restriction enzymes destroy unmodified DNA that is transferred between bacteria, irrespective of whether transfer is by bacteriophage infection, transformation or plasmid-mediated conjugation (Boyer, 1971). The enzymes are prevalent and diverse, being found in approximately one quarter of bacterial isolates and recognizing more than 200 specificities (Roberts \& Macelis, 1994; Barcus \& Murray, 1995). Hence, restriction is likely to be a frequently encountered barrier to the flow of DNA between bacterial strains in nature. Not surprisingly, phages and plasmids have evolved strategies for evading restriction (Bickle \& Krüger, 1993; Barcus \& Murray, 1995; Wilkins, 1995). One such strategy involves the activity of antirestriction genes.

The first plasmid-borne antirestriction gene to be described was $\operatorname{ard} A$. The locus was identified on conjugative plasmid ColIb-P9 of the IncI1 group and shown to act specifically against type I restriction enzymes (Delver $e t$ al., 1991; Read et al., 1992). Carriage of ard $A$ was found to protect unmodified Collb transferred by bacterial conjugation, with protection requiring expression of the gene in the transconjugant cell. Such a mode of action is consistent with the position of $\operatorname{ard} A$ in the plasmid leading region, defined as the first portion of the plasmid to enter the recipient cell (Read et al., 1992). An $\operatorname{ard} A$ homologue has also been found on the leading region of 
IncN plasmid pKM101, which contains an additional second antirestriction gene called $\operatorname{ardB}$ (Belogurov et al., 1992, 1993). Detection of conserved ard $A$ genes in the leading regions of IncI1 and IncN plasmids is remarkable, since these plasmids differ extensively in backbone portions involved in replication and transfer (Rees et al., 1987; Couturier et al., 1988; Pohlman et al., 1994; Lanka \& Wilkins, 1995).

The objective of the work described here was to determine the distribution and arrangement of $\operatorname{ard} A$ antirestriction genes on plasmids with the aim of elucidating the ecological role of the gene family. To this end, we examined representatives of 23 incompatibility (Inc) groups of enterobacterial conjugative plasmid for the presence of a conserved ard $A$ gene. We have also determined whether $\operatorname{ard} A$ genes are consistently linked to a particular type of origin of transfer (oriT) site or leading region gene. Well-characterized leading-region genes include plasmid ssb loci, determining classic singlestranded DNA-binding proteins (Chase et al., 1983; Golub \& Low, 1985; Howland et al., 1989), psiB, specifying a protein that interferes with the bacterial SOS response (Bagdasarian et al., 1986; Golub et al., 1988; Jones et al., 1992), and bok (fm) (Gerdes et al., 1986; Loh et al., 1988), which encodes an inducible toxin that kills cells from within (Sakikawa et al., 1989; Gerdes et al., 1990).

\section{METHODS}

Plasmids and bacterial strains. Conjugative plasmids were obtained from the collections of B. M. Wilkins, P. H. Williams (University of Leicester) and the National Collection of Type Cultures, London. IncFV plasmids and pBF105 (Finlay et al., 1986) were provided by L. Frost. pLG221 is ColIbdrd-1 cib: : Tn 5 (Howland et al., 1989). R387drd-86 was isolated as described for R16drd-86 (Bradley, 1984). pRS1078 is a pACYC184-derivative carrying $10.2 \mathrm{~kb}$ of the $\mathrm{F}$ plasmid leading region (Ray \& Skurray, 1983). Vectors used were pUC18 (Yanisch-Perron et al., 1988) and the lower copy-number plasmid pHG165 (Stewart et al., 1986). Recombinant plasmids constructed include: pLG2051 [pUC18 $\Omega\left(R 16\right.$ ard $A^{+}$PstI $2 \cdot 2$ kb)] ; pLG2052 [pUC18 $\Omega\left(\mathrm{R} 16\right.$ ard $\left.\left.A^{+} 0.62 \mathrm{~kb}\right)\right] ; \mathrm{pLG} 2053\left[\mathrm{pHG} 165 \Omega\left(\mathrm{F}_{0}\right.\right.$ lac ard $A^{+}$ EcoRI 11.5 kb)], Fig. 4; pLG2054 [pUC18 $\Omega\left(\mathrm{F}_{0} l a c^{\prime}\right.$ ard $A$ SalISpbI 3.3 kb)], Fig. 4. pLG2055, equivalent to pLG290 (Read et al., 1992), is pUC19 containing Collb ard $A^{+}$on a $2 \cdot 8 \mathrm{~kb}$ SalI-PstI fragment from pLG2012 (Rees et al., 1987). Sets of unidirectional deletions were produced by the method of Henikoff (1984). Bacterial strains included nalidixic acidresistant derivatives (designated by the suffix $N$ ) of C600 $\left(\mathrm{r}_{\mathbf{K}}^{+} \mathrm{m}_{\mathrm{K}}^{+}\right.$) and $5 \mathrm{~K}\left(\mathrm{r}_{\mathrm{K}}^{-} \mathrm{m}_{\mathrm{K}}^{+}\right.$; see Read et al., 1992), J53 (see Bradley, 1984) and BW85 (Rees et al., 1987).

Dotblot and Southern hybridizations. Genomic DNA was isolated by the method of Ausubel et al. (1991). Bacteria grown overnight in broth were lysed with SDS and proteins were removed by digestion with proteinase $\mathrm{K}$. Cell wall debris, polysaccharides and remaining proteins were removed by selective precipitation with hexadecyltrimethyl ammonium bromide- $\mathrm{NaCl}$ solution. DNA was recovered from the supernatant by isopropanol precipitation. Dotblots contained $10 \mathrm{ng}$ heat-denatured genomic DNA per spot. Hybridization was carried out at $65^{\circ} \mathrm{C}$ in the presence of $0.5 \mathrm{M}$ phosphate, $\mathrm{pH} 7 \cdot 2$, containing $7 \%$ SDS and $1 \mathrm{mM}$ EDTA (Church \& Gilbert, 1984). Post-hybridization washes were at $65^{\circ} \mathrm{C}$ in
$0.1 \times \mathrm{SSC}+0 \cdot 1 \%$ SDS (high stringency), $0.5 \times \mathrm{SSC}+0.1 \%$ $\mathrm{SDS}$ (medium stringency) or $3 \times \mathrm{SSC}+0.1 \% \mathrm{SDS}$ (low stringency). Other methods, including radiolabelling of probes, were as previously described by Howland et al. (1989).

Probes. PCR-derived probes were synthesized using Taq DNA polymerase. Primers for PCR were, for Collb ard A (Read et al., 1992) , 5'-GGCATATGTCTGTTGTTGCACCTG-3' and 5'CCGGATCCTCACCGACGGAACACAT- $3^{\prime}$ and, for pKM101 ard $A$ (Belogurov et al., 1992), 5'-GGGGATCCATGACTGATATTACGACC- $3^{\prime}$ and $5^{\prime}$-CCAAGCTTTCAGCAAGTCATGTTAAA-3'. Identities of ColIb and pKM101 PCR products were verified by sizing fragments generated by $S m a \mathrm{I}$ and $A c c \mathrm{I}$, respectively. The $p n d$ and bok probes extended from residue 140 to 562 in the alignments of Gerdes et al. (1990), and were synthesized using 18-mer primers; pAN-1 (Nielsen et al., 1991) and pPR311 (Rasmussen et al., 1987) were templates. Other probes included a $1.55 \mathrm{~kb}$ Pst I fragment for Collb oriT (Rees et al., 1987), a $0.53 \mathrm{~kb} E c o \mathrm{RV}$ fragment of R6-5 for psiB (see Jones $e t a l$., 1992), and a $0.7 \mathrm{~kb}$ AvalI fragment of $\mathrm{F}$ for $s s b$ (see Howland et al., 1989).

Nucleotide sequencing. Sequencing was performed on denatured double-stranded plasmid DNA using either the Sequenase version $2.0 \mathrm{kit}$ (USB) or the Cyclist $\mathrm{Exo}^{-} \mathrm{Pfu}$ sequencing kit (Stratagene). Primers included M13 universal and reverse primers. 18-mers complementary to $\mathrm{F}_{0}$ lac sequences were also used on pLG2053 templates. Data were analysed using the GCG package (version 7).

Genetic tests. Phage $\lambda$ assays were as previously described (Read et al., 1992). Mobilization frequencies of oriT recombinants were determined as before (Rees et al., 1987), with conjugation occurring on the surface of a nitrocellulose disk for $60 \mathrm{~min}$. The oriT recombinant was pLG2009, except for tests with an Ap conjugative plasmid when pLG2008 was used. The assay for the $\mathrm{Pnd}^{+}$phenotype involved incubation of brothgrowing bacteria in the presence of $200 \mu \mathrm{g}$ rifampicin ml ${ }^{-1}$ for $40 \mathrm{~min}$ at $37^{\circ} \mathrm{C}$. Cell suspensions were then plated on nutrient agar to determine loss of colony-forming ability.

\section{RESULTS}

\section{Distribution of ard genes on enterobacterial conjugative plasmids}

The initial screen was for homologues detectable by hybridization to a probe of ColIb ard $A$. The gene was identified previously as an ORF encoding a predicted $19 \mathrm{kDa}$ polypeptide of 166 amino acid residues (Delver $e t$ al., 1991; Read et al., 1992). Probe was prepared from PCR-amplified ard $A$ coding sequence and tested for hybridization to DNA samples representing 23 Inc groups of plasmid characterized in E. coli and other enteric bacteria. The standard method involved dotblots of total genomic DNA tested at the lowest stringency sufficient to eliminate non-specific-binding of the probe to the plasmid-free hosts BW85, C600 and J53. These strains represent different $E$. coli $\mathrm{K} 12$ pedigrees. Table 1 shows that $\operatorname{ard} A$-hybridizing sequences were detected on plasmids representing IncB, FV, I1, $\mathrm{K}$ and $\mathrm{N}$ groups. Fig. 1 illustrates the intensities of representative signals. No further group of plasmids was identified as hybridization positive when the test was repeated using PCR amplified pKM101 ard $A$ as probe.

In addition to the IncFI, FII, FIV, $\mathrm{I} 2$ and $\mathrm{X}$ plasmids listed in Table 1 , the following groups were found to lack 
Table 1. Carriage of ardA, ssb, psiB and hok-family genes by some enterobacterial plasmids

Presence/absence of a sequence hybridizing to the appropriate probe is indicated by \pm .

\begin{tabular}{|c|c|c|c|c|c|}
\hline \multirow[t]{2}{*}{ Inc group } & \multirow[t]{2}{*}{ Plasmid(s) } & \multirow[t]{2}{*}{$\operatorname{ard} A^{*}$} & \multirow[t]{2}{*}{$s s b-p s i B+$} & \multicolumn{2}{|c|}{ hok family } \\
\hline & & & & hok & pred \\
\hline \multicolumn{6}{|l|}{ F complex } \\
\hline FI & F, R386 & - & + & + & - \\
\hline FII & $\mathrm{R} 1 d r d-16, \mathrm{R} 100 d r d-1$ & - & + & + & - \\
\hline FIV & R124 & - & + & + & - \\
\hline $\mathrm{FV}$ & $\mathrm{F}_{0} l a c$ & + & + & + & - \\
\hline \multicolumn{6}{|l|}{ I complex } \\
\hline $\mathrm{B}$ & R16, R621a & + & + & - & + \\
\hline I1 & Collb-P9, R64 & + & + & - & + \\
\hline $\mathrm{I} 2$ & R721, TP114 & - & - & + & - \\
\hline $\mathrm{K}$ & R387 & + & + & - & + \\
\hline \multicolumn{6}{|l|}{ Others } \\
\hline $\mathrm{N}$ & pKM101, N3 & + & - & - & - \\
\hline $\mathrm{X}$ & $\mathrm{R} 6 \mathrm{~K}$ & - & - & - & - \\
\hline
\end{tabular}

* Plasmids classified as negative for $\operatorname{ard} A$ hybridization were $\mathrm{Ard}^{-}$in the functional test.

†The single + indicates carriage of the genes as a pair; with the exception of $\mathrm{F}_{0} l a c$ (this work), ssb and psiB data are from Golub et al. (1988) and refer to the Inc group rather than the named plasmids.

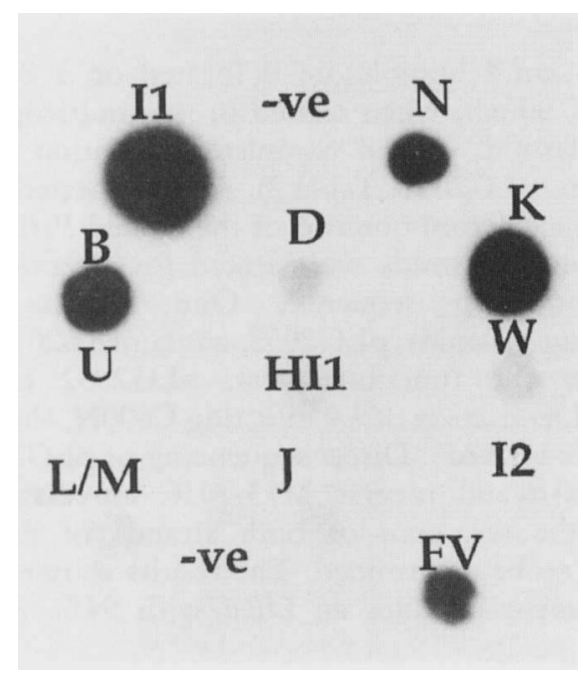

Fig. 1. Dotblot hybridizations at low stringency to the Collb ardA probe. Genomic DNA of bacteria harbouring a plasmid of the indicated Inc group was used. Plasmids were Collb-P9 (I1), pKM101 (N), R16 (B), R711b (D), R387 (K), RA3 (U), R27 (HI1), pS-a (W), R446b (L/M), R391 (J), TP114 (I2) and Folac (FV). DNA of plasmid-free $\mathrm{C} 600$ and $J 53$ were the negative (-ve) controls. At high stringency, a positive signal was obtained only for I1, B and $K$ plasmids. Weak signals produced by $D, H I 1, J$ and $W$ plasmids at low stringency were not detected at medium stringency. Prolonged exposure was required to detect signals from $\mathrm{FV}$ and $\mathrm{N}$ plasmids at medium stringency.

an ard $A$-hybridizing sequence as judged by tests with bacteria harbouring the indicated plasmids: A/C (RA1, R40a), Com9 (R71a), D (R711b), HI1 (R27), HI2 (R478,
pSD114), HII (pHH1508a), J (R391), L/M (R446b, R471), P(RP4, R751), T (Rts-1), U (RA3), W (pS-a, R388) and $\mathrm{Y}(\mathrm{P} 1 \mathrm{Cm})$. It was noted that a probe consisting of a Collb restriction fragment containing $\operatorname{ard} A$ plus flanking sequences of $\sim 360$ bp hybridized at high stringency with the representative Com9, IncFI, FII, FIV and HI2 plasmids. The positive signals presumably reflect sequence similarities between regions that border the $\operatorname{ard} A$ locus and emphasize the need to use a probe limited to the coding sequence.

IncFV plasmid $\mathrm{F}_{0}$ lac stands out among $\mathrm{F}$ complex plasmids in containing an ard $A$-homologue. To check that other F-like plasmids lack such a sequence, restriction digests of plasmids F, R1drd-16, R100drd-1 and R124 were tested following Southern blotting for hybridization to the ColIb $\operatorname{ard} A$ probe. The test was also applied to pRS1078, which is a recombinant carrying the F leading region (Ray \& Skurray, 1983). No hybridization was detected at low stringency to any F-type sequence with the exception of $\mathrm{F}_{0}$ lac.

Equivalent hybridization tests were carried out with a probe consisting of PCR product to the pKM101 $\operatorname{ardB}$ coding sequence. Hybridization was found only to pKM101 and N3 of the IncN group.

\section{Plasmids with ardA-hybridizing sequences specify an antirestriction phenotype}

The functional assay for $\operatorname{ard} A$ measures alleviation of restriction of unmodified dvir following infection of a strain (C600N) expressing the EcoKI R-M system (Read $e t$ 
Table 2. Alleviation of EcoKI restriction of unmodified $\lambda v i r$ in plasmid-containing cells

\begin{tabular}{|lccc|}
\hline & \multicolumn{3}{c|}{ Restriction-alleviation index* } \\
\cline { 2 - 4 } Plasmid in & $\begin{array}{c}\text { Native } \\
\text { strain C600 }\end{array}$ & $\begin{array}{c}\text { drd mutant } \\
\text { of plasmid }\end{array}$ & $\begin{array}{c}\text { Multicopy } \\
\text { recombinant }\end{array}$ \\
\hline ColIb (IncI1) & 26 & 164 & 7000 \\
R16 (IncB) & 27 & 180 & 7100 \\
R387 (IncK) & 24 & 127 & NT \\
F lac (IncFV) & 22 & 150 & 4300 \\
pKM101 (IncN) & 23 & NA & NT \\
\hline
\end{tabular}

NT, Not tested.

NA, Not available.

* Defined as the efficiency of plating (e.o.p.) of $\lambda$ vir. 0 on $\mathrm{C} 600 \mathrm{~N}$ harbouring the plasmid divided by e.o.p. on plasmid-free $\mathrm{C} 600 \mathrm{~N}$. The value for the latter was $1.4 \times 10^{-4}$. An index of 7100 indicates complete restriction alleviation. Appropriate $d r d$ mutants were pLG221 (ColIb-P9), R16drd-86, R387drd-86 and pED208 ( $\left.\mathrm{F}_{0} l a c\right)$. Multicopy recombinants were pLG2055 (ColIb), pLG2051 (R16) and pLG2053 ( $\mathrm{F}_{0}$ lac $)$.

al., 1992). The assay showed that restriction was alleviated by about 25 -fold when $\mathrm{C} 600 \mathrm{~N}$ harboured a representative of each of the five Inc groups of plasmid with $\operatorname{ard} A$ homology (Table 2). Yet higher levels of restriction alleviation were detected when wild-type ColIb, $\mathrm{F}_{0}$ lac, R16 and R387 were replaced with plasmids with a drd mutation that derepresses expression of the transfer genes. The restriction-alleviation index of $\mathrm{C} 600 \mathrm{~N}$ carrying $\mathrm{F}$, R1drd-16, R100drd-1 or pRS1708 was $1 \cdot 0$, showing that standard IncFI and IncFII plasmids and the recombinant with the $\mathrm{F}$ leading region lack a gene that can function in vegetative cells to alleviate type I restriction systems. Similarly, the FIV, I2 and X plasmids failed to alleviate restriction in the functional test (Table 1).

\section{Linkage of ardA to leading region genes on $B$ and $K$ plasmids}

ColIb, R16 and R387 belong to the I1-B-K subset of the I complex of incompatibility groups (Bradley, 1984). Subset members have homologous replicons (Couturier $e t$ al., 1988), encode similar conjugative pili (Bradley, 1984), and carry conserved $s s b$ and $p s i B$ genes (Golub et al., 1988). Moreover, the subset determines functionally similar DNA transfer systems as demonstrated by their ability to mobilize small ColIb oriT recombinants with high to intermediate frequencies (data of $\mathrm{A}$. T. Thomas \& B. M. Wilkins). Mobilization abilities, defined as the frequency of transfer of the oriT recombinant relative to the conjugative plasmid, were 0.94 for ColIbdrd-1(I1), $2.5 \times 10^{-2}$ for R387 (K) and $3.0 \times 10^{-4}$ for R16drd-86 (B). Values in negative controls were $5.2 \times 10^{-7}$ for TP114drp1 (I2) and $7 \cdot 0 \times 10^{-7}$ for pUB307 (P).

The similarities were exploited to determine the sector of $\mathrm{R} 16$ and R387 carrying the ard $A$ sequence. To this end, R16 and R387 were cleaved with restriction enzymes that cut infrequently and fragments were tested following Southern transfer for hybridization to probes containing ColIb oriT, F ssb and R6-5 psiB. Each probe hybridized at high stringency to a $25 \mathrm{~kb} \mathrm{Bam} \mathrm{HI}$ fragment of R16 and to a $23 \mathrm{~kb}$ EcoRI fragment of R387. The same fragments were recognized by the ColIb ard $A$ PCR product, indicating that the ard $A$ homologue is located in a sector of R16 and R4387 that includes oriT and leading region genes.

\section{Nucleotide sequence of ardA on an IncB plasmid}

The R16 ard $A$ homologue is located on a $2 \cdot 2 \mathrm{~kb}$ Pst fragment, which, when cloned in the multicopy pUC18 vector plasmid, caused complete alleviation of EcoKI restriction (pLG2051, Table 2). A set of nested deletions was produced from one end of the cloned PstI fragment and deletion plasmids were tested for retention of the $\operatorname{ard} A$-hybridizing sequence. One of the smallest hybridizing plasmids, pLG2052, contained 620 bp of R16 DNA. In the functional test, pLG2052 completely alleviated restriction of $\lambda .0$ infecting $C 600 \mathrm{~N}$, showing the plasmid to be $\mathrm{Ard}^{+}$. Direct sequencing of pLG2052 from the forward and reverse M13/pUC universal primers allowed the sequence of both strands of the cloned fragment to be determined. The results showed that the R16 fragment includes an ORF with $94 \%$ nucleotide

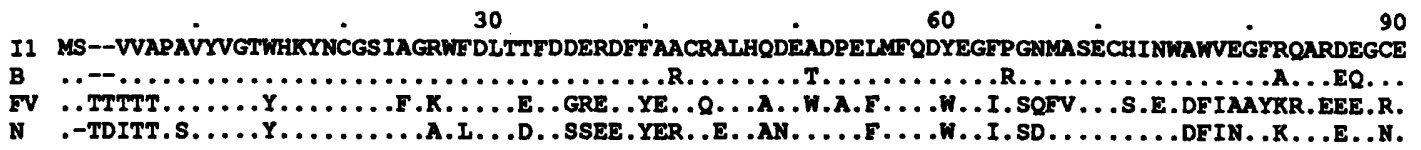




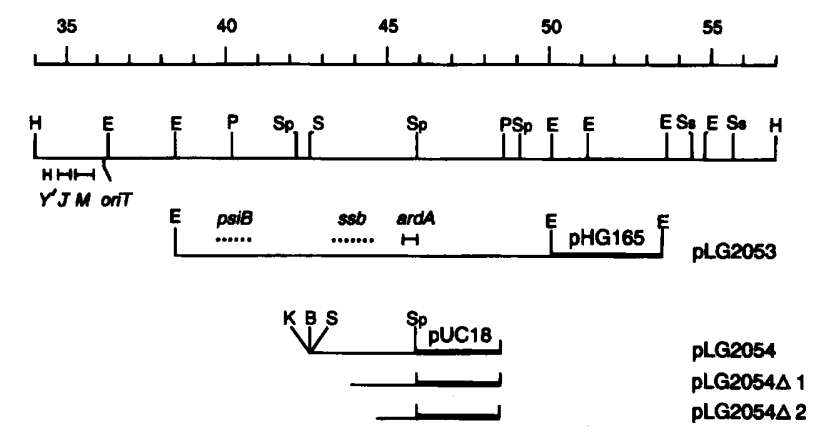

Fig. 3. Leading region of IncFV plasmid $F_{0}$ lac. Kilobase coordinates are those of Finlay et al. (1986). Line 2 shows restriction sites mapped on the $23 \mathrm{~kb}$ Hind III fragment. The location of oriT, traM, traJ and the promoter-proximal portion of tra $Y$ were derived by Di Laurenzio et al. (1991). Dotted lines indicate the approximate position of ssb and psiB. pLG2054 1 and pLG2054 22 represent linear plasmid deletants produced by unidirectional digestion of pLG2054 from the BamHI site in the polylinker. Restriction sites: B, BamHI; E, EcoRI; H, HindlII; K, Kpnl; P, Pvul; S, Sall; Sp, Sphl.

sequence identity to ColIb $\operatorname{ard} A$. The nucleotide sequence is available as accession number Z34468 in the EMBL database. The predicted amino acid sequence of the product is given in Fig. 2.

\section{Location and nucleotide sequence of $\operatorname{ard} A$ on an IncFV plasmid}

Plasmid pED208 is a mutant of $\mathrm{F}_{0}$ lac that is derepressed for transfer. Southern hybridization showed the $\operatorname{ard} A$ related sequence to be on the $\sim 23 \mathrm{~kb}$ HindIII fragment which contains oriT and the pED208 leading region and is present in recombinant $\mathrm{pBF} 105$ (Finlay et al., 1986). The $\operatorname{ard} A$ hybridizing sequence was delimited further to a $11.5 \mathrm{~kb}$ EcoRI fragment, carried by pLG2053, and then to a $3.3 \mathrm{~kb}$ SpbI-SalI fragment, carried by pLG2054 (Fig. 3). Although pLG2053 was Ard ${ }^{+}$(Table 2), pLG2054 failed to alleviate EcoKI restriction indicating that it lacks a functional $\operatorname{ard} A$ gene.

Direct sequencing of pLG2054 from the forward M13/ pUC universal primers showed that the SpbI site is located $\sim 120 \mathrm{bp}$ downstream of the $5^{\prime}$-end of an ard $A$-type sequence. Although the 5 -terminal third portion of ColIb $\operatorname{ard} A$ is inessential for conferring an $\mathrm{Ard}^{+}$phenotype on vegetative cells (Read et al., 1992), the partial ard $A$ gene in pLG2054 is in the promoterless orientation. The finding that the $S p b$ I site is towards the $5^{\prime}$-end of ard $A$ defines the direction of transcription of the gene on pED208 as being towards oriT. Data obtained from pLG2054 were used to design primers for sequencing both strands of $\operatorname{ard} A^{+}$on pLG2053. The nucleotide sequence has the EMBL accession number Z34467. The derived amino acid sequence is given in Fig. 2.

\section{$F_{0} l a c$ ardA is linked to ssb, psiB and hok leading region genes}

Southern hybridizations showed pED208 to contain $s s$, $p s i B$ and bok sequences, as is the case for plasmid F. Tests

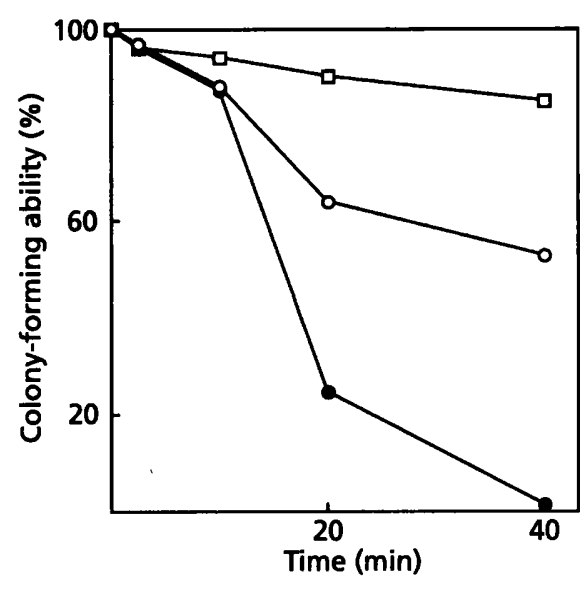

Fig. 4. E15 fragment of Collb-P9 specifies the Hok ${ }^{+}$phenotype. Values show colony-forming ability of plasmid-containing cells following incubation in the presence of rifampicin for the indicated times. $\square$, BW85(pHG165); 0 , BW85(Collbdrd-1); 0 , BW85(pMC3).

with pLG2053 fragments showed the $p s i B$ probe to recognize the EcoRI insert and to anneal with approximately equal intensities to the $1.7 \mathrm{~kb} P v u \mathrm{I}-E c o \mathrm{RI}$ and the $2.0 \mathrm{~kb}$ PvuI-SphI fragments (Fig. 3). Hence, pED208 psiB maps at coordinate $40.2 \pm 0.5 \mathrm{~kb}$, the latter value being the size of a $p s i B$ locus. The $s s b$ probe hybridized to the EcoRI insert in pLG2053 and to the $3.3 \mathrm{~kb}$ SphI-SalI fragment present in pLG2054. The hybridizing region was mapped further by testing for its retention on pLG2054derivatives progressively deleted from one end of the cloned fragment (Fig. 3). Molecules of the size of pLG2054 $\Delta 1$ but not $-\Delta 2$ retained the $s s b$-hybridizing region. Hence, $\mathrm{pED} 208$ ssb maps close to coordinate $44.0 \pm 0.5 \mathrm{~kb}$, the latter value approximating to the size of a plasmid ssb gene (Chase et al., 1983; Howland et al., 1989). The pED208 leading region also contains a $\mathrm{fm}$ homologue, shown by hybridization of the bok probe to a $2 \cdot 2 \mathrm{~kb}$ EcoRI fragment that flanks oriT.

\section{Collb-P9 carries a hok-family gene outside the leading region}

Plasmid-borne members of the bok family include the bok $(\mathrm{fm})$ and $p n d$ subfamilies (Sakikawa $\mathrm{et}$ al., 1989; Gerdes $\mathrm{et}$ al., 1990). The bok probe failed to recognize Collb but the pnd probe hybridized to the $16 \mathrm{~kb}$ Sall (S3) fragment and the $1.9 \mathrm{~kb}$ EcoRI (E15) fragment therein (for map, see Rees et al., 1987). To confirm that the pnd-type sequence is a functional killer gene, the $1.9 \mathrm{~kb}$ EcoRI fragment was inserted in vector $\mathrm{pHG} 165$ to give $\mathrm{pMC} 3$. This recombinant specified a pronounced $\mathrm{Hok}^{+}$phenotype, as indicated by loss of viability of host cells incubated with rifampicin (Fig. 4). The drug induces killing by preventing synthesis of the short-lived RNA molecules that regulate synthesis of the toxin (Sakikawa et al., 1989; Nielsen et al., 1991). The combined data indicate that the ColIb trailing region, defined as the last portion of the plasmid to enter the recipient cell, contains a pnd gene 
located some $5 \cdot 4-7 \cdot 3 \mathrm{~kb}$ from oriT. IncB and IncK plasmids also carry pnd. The gene maps outside the leading region, since the probe hybridized to $6.6 \mathrm{~kb}$ Bam HI fragment of R16 and to a $2.8 \mathrm{~kb}$ EcoRI fragment of R387. These fragments differ from those identified above as carrying oriT, ssb, $p s i B$ and $\operatorname{ard} A$.

\section{DISCUSSION}

Hybridization tests showed that sequences homologous to the Collb ard $A$ antirestriction gene are present on plasmids belonging to the $\mathrm{B}, \mathrm{FV}, \mathrm{I} 1, \mathrm{~K}$ and $\mathrm{N}$ incompatibility groups. The homologue on the IncN plasmids is assumed to be the antirestriction gene described by Belogurov et al. (1992) and was not examined further. The hybridizing regions on the $\mathrm{B}$ and FV plasmids were shown to contain an ORF related to Collb $\operatorname{ard} A$. Nucleotide positional identities for the $\operatorname{ard} A$ genes are ColIb/R16, 95\%; ColIb/F $/$ lac, $63 \%$; Collb/ pKM101, 62\%; pKM101/ $\mathrm{F}_{0}$ lac, $64 \%$. Hence, the hybridization assay readily detected genes diverged by about $40 \%$. The predicted protein products have 166 (Collb and R16), 168 ( $\mathrm{F}_{0}$ lac) and 169 (pKM101) amino acid residues and are highly acidic, with net charges ranging from -22 for $\mathrm{R} 16$ ArdA, to -29 for $\mathrm{F}_{0}$ lac ArdA. The ard $A$ homologues on $\mathrm{R} 16$ and $\mathrm{F}_{0} l a c$ are inferred to be functional antirestriction genes. The evidence is that the $\mathrm{R} 16$ homologue was delimited to a $620 \mathrm{bp}$ fragment that determines the restriction-alleviation phenotype, while disruption of the $\mathrm{F}_{0} l a c$ ard $A$ sequence by subcloning destroyed the antirestriction phenotype conferred by a larger fragment carrying the intact gene. Less attention was given to $\operatorname{ard} A$ on IncK plasmids in view of their close relationship to IncB and 11 plasmids.

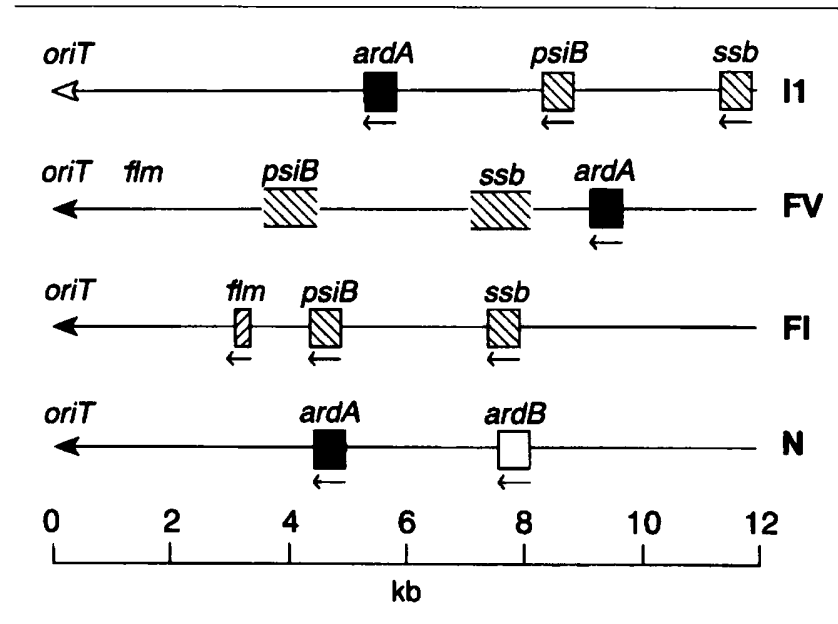

Fig. 5. Content and arrangement of genes on the leading region of representative 11 (CollbP-9), $\mathrm{FV}\left(\mathrm{F}_{0} / a \mathrm{C}\right), \mathrm{FI}(\mathrm{F})$ and $\mathrm{N}$ (pKM101) plasmids. Arrows under genes indicate known directions of transcription. Map limits for $f(m, p s i B$ and ssb on $\mathrm{F}_{0}$ lac are described in the text. Data for the $11, \mathrm{FI}$ and $\mathrm{N}$ plasmids are from Read et al. (1992), Bagdasarian et al. (1992) and Belogurov et al. (1993), respectively. orit shading indicates sequence relationships at the nick region (Lanka \& Wilkins, 1995).
While B, I1 and K plasmids are classified with I2 plasmids into the I complex of incompatibility groups (Bradley, 1984), I 2 plasmids lack a conserved ard $A$ gene. This is unsurprising in view of the extensive differences between the B-I1-K subset and I2 plasmids, which are manifest by replicon typing (Couturier et al., 1988), properties of conjugative pili (Bradley, 1984), ability to mobilize ColIb ori $T$ recombinants (see above), and carriage of $s s b, p s i B$ and pnd genes (Table 1). A more intriguing finding is that FV plasmid $\mathrm{F}_{0}$ lac is unique among the $\mathrm{F}$-type plasmids examined in carrying a conserved $\operatorname{ard} A$ gene. This is remarkable because F-like groups have homologous transfer systems, ori $T$ s and leading regions (Ippen-Ihler \& Skurray, 1993; Lanka \& Wilkins, 1995; Table 1). No evidence was obtained that $F$ or standard FII plasmids specify an antirestriction function active against the classic type I restriction enzyme EcoKI. Conjugative transposon Tn916 from Enterococcus faecalis has a sequence (ORF18) predicted to specify a 166 amino acid product with $26 \%$ amino acid sequence identity to ArdA (Flannagan et al., 1994). The function of ORF18 is unknown but it maps in the portion of $\operatorname{Tn} 916$ which is necessary for conjugation.

Plasmids can carry other genes active against type I restriction systems, as shown by the presence of $\operatorname{ardB}$ of $\mathrm{pKM} 101$. The gene is non-homologous to $\operatorname{ard} A$ but maps in the leading region (Belogurov et al., 1993; Fig. 5). Conserved $\operatorname{ard} B$ genes appear to have a limited distribution, since PCR-amplified ardB hybridized only to the two IncN plasmids (pKM101 and N3) in our sample of plasmids (unpublished data). It is unknown what ecological advantage the carriage of two different ard genes confers on IncN plasmids. A sequence $(k \operatorname{lc} A)$ sharing $39 \%$ nucleotide sequence identity with pKM101 ard $B$ and predicted to encode an acidic 146 amino acid polypeptide has been identified on IncP $\alpha$ plasmids. However, $k l c A$ differs from $\operatorname{ard} B$ in being located outside the leading region and in failing to alleviate EcoKI restriction, even when carried by a high-copy-number vector (Larsen \& Figurski, 1994). It is unlikely that klc $A$ contributes to an antirestriction system that is activated during conjugation, since transconjugant production by unmodified RP4 is $\sim 100$-fold more sensitive to EcoKI restriction than is the case for unmodified ColIbdrd-1 (data of A. T. Thomas \& B. M. Wilkins). Both plasmids are thought to have similar numbers of EcoKI sites: there are nine sites in the nucleotide sequence of RP4 (Pansegrau $e t$ al., 1994), and an estimated seven on ColIb. The latter value is derived from the finding of four EcoKI sites in the $54 \mathrm{~kb}$ nucleotide sequence of the Tra region on IncI1 plasmid R64 (T. Komano, personal communication).

A unifying feature of ard genes is their location in plasmid leading regions. Here the genes are found in heterogeneous assemblies with members of other gene families, namely $s s b, p s i B$ and bok (Fig. 5). It is stressed that there is no consistent association between $\operatorname{ard} A$ and any other known leading region gene or type of oriT. Transfer regions can be typed according to the sequence of the nick region, defined as the oriT subregion recognized by the plasmid-encoded relaxase for the cleavage and joining of 
DNA strands during conjugation. Three types have been identified: the nick region of FI, FII, FV and N plasmids constitute one type, whereas the I1 nick region belongs to a second type exemplified by IncP plasmids (Lanka \& Wilkins, 1995). Taken together, the evidence suggests that $\operatorname{ard} A$ genes are recent accretions to leading regions. This conclusion is consistent with the different position of $\operatorname{ard} A$ relative to oriT and $p s i B$ on the $\mathrm{I} 1$ and $\mathrm{FV}$ plasmids. Despite these organizational variations, it is impressive that the transcriptional orientation of ard, ssb and $p s i B$ is the same in each case examined (Fig. 5). The arrangement, which causes the transcribed strand to be the same as the transferred strand, may be important for the expression of the genes during conjugation (Jones et al., 1992; Read et al., 1992).

It is unclear why some plasmids carry $\operatorname{ard} A$ genes but others do not. The ard $A^{+}$elements identified here are judged to be authentic enterobacterial plasmids, since they were isolated from organisms closely related to $E$. coli (Lanka \& Wilkins, 1995). Furthermore, F complex, I complex and IncN plasmids constitute part of the defined plasmid population of a set of Eschericbia, Shigella, Salmonella and Klebsiella strains collected by E. D. G. Murray in the period between 1917 and 1954 (Datta \& Hughes, 1983). Type I R-M systems have historically been associated with a similar cluster of enterobacterial organisms. It is tempting therefore to conclude that $\operatorname{ard} A$ has the ecological role of allowing plasmids to evade a particular type of restriction system prevalent in their natural hosts. However, this conclusion does not accommodate the finding that some 'Murray' plasmids lack a conserved $\operatorname{ard} A$ gene (see FII, I 2 and X plasmids; Table 1). Moreover, type I R-M systems are now recognized to be more widely distributed than previously considered (Barcus \& Murray, 1995), as shown by the recent discovery of such a system in Mycoplasma pulmonis (Dybvig \& $\mathrm{Yu}, 1994$ ) and in Bacillus subtilis (T. A. Trautner, personal communication).

\section{ACKNOWLEDGEMENTS}

We thank Laura Frost for the gift of $\mathrm{F}_{0}$ lac, pED208 and pBF105, Noreen Murray and Lise Raleigh for perspectives on the distribution and detection of type I restriction systems, and Angela Thomas for unpublished data. P.M.C. was a research student funded by the Medical Research Council. The work was supported by MRC grant G9321196MB.

\section{REFERENCES}

Ausubel, F. M., Brent, R., Kingston, R. E., Moore, D. D., Seidman, J. G., Smith, J. A. \& Struhl, K. (1990). Current Protocols in Molecular Biology, vol. 1, pp. 2.4.1-2. New York: John Wiley \& Sons.

Bagdasarian, M., Bailone, A., Bagdasarian, M. M., Manning, P. A., Lurz, R., Timmis, K. N. \& Devoret, R. (1986). An inhibitor of SOS induction, specified by a plasmid locus in Eschericbia coli. Proc Natl Acad Sci US A 83, 5723-5726.

Bagdasarian, M., Bailone, A., Angulo, J. F., Scholz, P., Bagdasarian, M. \& Devoret, R. (1992). PsiB, an anti-SOS protein, is transiently expressed by the $\mathrm{F}$ sex factor during its transmission to an Escherichia coli K-12 recipient. Mol Microbiol 6, 885-893.
Barcus, V. A. \& Murray, N. E. (1995). Barriers to recombination: restriction. In Population Genetics of Bacteria, Society for General Microbiology Symposium 52, pp. 31-58. Edited by S. Baumberg, J. P. W. Young, E. M. H. Wellington \& J. R. Saunders. Cambridge: Cambridge University Press.

Belogurov, A. A., Delver, E. P. \& Rodzevich, O. V. (1992). IncN plasmid pKM101 and IncI1 plasmid ColIb-P9 encode homologous antirestriction proteins in their leading regions. $J$ Bacteriol 174, 5079-5085.

Belogurov, A. A., Delver, E. P. \& Rodzevich, O. V. (1993). Plasmid pKM101 encodes two nonhomologous antirestriction proteins (ArdA and ArdB) whose expression is controlled by homologous regulatory sequences. $J$ Bacteriol 175, 4843-4850.

Bickle, T. A. \& Kruger, D. H. (1993). Biology of DNA restriction. Microbiol Rev 57, 434-450.

Boyer, H. W. (1971). DNA restriction and modification mechanisms in bacteria. Annu Rev Microbiol 25, 153-176.

Bradley, D. E. (1984). Characteristics and function of thick and thin conjugative pili determined by transfer-derepressed plasmids of incompatibility groups $I_{1}, I_{2}, I_{5}, B, K$ and $Z$. $J$ Gen Microbiol 130, 1489-1502.

Chase, J. W., Merrill, B. M. \& Williams, K. R. (1983). F sex factor encodes a single-stranded DNA binding protein (SSB) with extensive sequence homology to Escherichia coli SSB. Proc Natl Acad Sci US A 80, 5480-5484.

Church, G. M. \& Gilbert, W. (1984). Genomic sequencing. Proc Natl Acad Sci US A 81, 1991-1995.

Couturier, M., Bex, F., Bergquist, P. L. \& Maas, W. K. (1988). Identification and classification of bacterial plasmids. Microbiol Rev 52, 375-395.

Datta, N. \& Hughes, V. M. (1983). Plasmids of the same Inc groups in Enterobacteria before and after the medical use of antibiotics. Nature 306, 616-617.

Delver, E. P., Kotova, V. U., Zavilgelsky, G. B. \& Belogurov, A. A. (1991). Nucleotide sequence of the gene (ard) encoding the antirestriction protein of plasmid Collb-P9. J Bacteriol 173, 5887-5892.

Di Laurenzio, L., Frost, L. S., Finlay, B. B. \& Paranchych, W. (1991). Characterization of the ori $T$ region of the IncFV plasmid pED208. Mol Microbiol 5, 1779-1790.

Dybvig, K. \& Yu, H. (1994). Regulation of a restriction and modification system via DNA inversion in Mycoplasma pulmonis. Mol Microbiol 12, 547-560.

Finlay, B. B., Frost, L. S. \& Paranchych, W. (1986). Nucleotide sequence of the tra $Y A L E$ region from IncFV plasmid pED208. $J$ Bacteriol 168, 990-998.

Flannagan, S. E., Zitzow, L. A., Su, Y. A. \& Clewell, D. B. (1994). Nucleotide sequence of the 18-kb conjugative transposon Tn916 from Enterococcus faecalis. Plasmid 32, 350-354.

Gerdes, K., Rasmussen, P. B. \& Molin, S. (1986). Unique $i_{J^{-}}$of plasmid maintenance: postsegregation killing of plasmid-free cells. Proc Natl Acad Sci US A 83, 3116-3120.

Gerdes, K., Poulsen, L. K., Thisted, T., Nielsen, A. K., Martinussen, J. \& Andreasen, P. H. (1990). The bok killer gene family in Gramnegative bacteria. New Biol 2, 946-956.

Golub, E. I. \& Low, K. B. (1985). Conjugative plasmids of enteric bacteria from many different incompatibility groups have similar genes for single-stranded DNA-binding proteins. J Bacteriol 162, 235-241.

Golub, E. I., Bailone, A. \& Devoret, R. (1988). A gene encoding an 
SOS inhibitor is present in different conjugative plasmids. J Bacteriol 170, 4392-4394.

Henikoff, S. (1984). Unidirectional digestion with exonuclease III creates targeted breakpoints for DNA sequencing. Gene 28, 351-359.

Howland, C. J., Rees, C. E. D., Barth, P. T. \& Wilkins, B. M. (1989). The ssb gene of plasmid ColIb-P9. J Bacteriol 171, 2466-2473.

Ippen-Ihler, K. \& Skurray, R. A. (1993). Genetic organization of transfer-related determinants on the sex factor $F$ and related plasmids. In Bacterial Conjugation, pp. 23-52. Edited by D. B. Clewell. New York: Plenum Press.

Jones, A. L., Barth, P. T. \& Wilkins, B. M. (1992). Zygotic induction of plasmid $s s b$ and $p s i B$ genes following conjugative transfer of IncI1 plasmid ColIb-P9. Mol Microbiol 6, 605-613.

Lanka, E. \& Wilkins, B. M. (1995). DNA processing reactions in bacterial conjugation. Annu Rev Biochem 64, 141-169.

Larsen, M. H. \& Figurski, D. H. (1994). Structure, expression, and regulation of the kilC operon of promiscuous $\operatorname{IncP} \alpha$ plasmids. $J$ Bacteriol 176, 5022-5032.

Loh, S. M., Cram, D. S. \& Skurray, R. A. (1988). Nucleotide sequence and transcriptional analysis of a third function (Flm) involved in Fplasmid maintenance. Gene 66, 259-268.

Nielsen, A. K., Thorsted, P., Thisted, T., Wagner, E. G. H. \& Gerdes, K. (1991). The rifampicin-inducible genes $s r n B$ from $F$ and pnd $A$ from $\mathrm{R} 483$ are regulated by antisense RNAs and mediate plasmid maintenance by killing of plasmid-free segregants. Mol Microbiol 5, 1961-1973.

Pansegrau, W., Lanka, E., Barth, P. T., Figurski, D. H., Guiney, D. G., Haas, D., Helinski, D. R., Schwab, H., Stanisich, V. A. \& Thomas, C. M. (1994). Complete nucleotide sequence of Birmingham IncP $\alpha$ plasmids. $J$ Mol Biol 239, 623-663.

Pohlman, R. F., Genetti, H. D. \& Winans, S. C. (1994). Common ancestry between IncN conjugal transfer genes and macromolecular export systems of plant and animal pathogens. Mol Microbiol 14, $655-668$.
Rasmussen, P. B., Gerdes, K. \& Molin, S. (1987). Genetic analysis of the parB $B^{+}$locus of plasmid R1. Mol \& Gen Genet 209, 122-128.

Ray, A. \& Skurray, R. (1983). Cloning and polypeptide analysis of the leading region in F plasmid DNA transfer. Plasmid 9, 262-272.

Read, T. D., Thomas, A. T. \& Wilkins, B. M. (1992). Evasion of type I and type II DNA restriction systems by IncI1 plasmid ColIb-P9 during transfer by bacterial conjugation. Mol Microbiol 6, 1933-1941.

Rees, C. E. D., Bradley, D. E. \& Wilkins, B. M. (1987). Organization and regulation of the conjugation genes of Incl $_{1}$ plasmid ColIb-P9. Plasmid 18, 223-236.

Roberts, R. J. \& Macelis, D. (1994). REBASE - restriction enzymes and methylases. Nucleic Acids Res 22, 3628-3639.

Sakikawa, T., Akimoto, S. \& Ohnishi, Y. (1989). The pnd gene in E. coli plasmid R16: nucleotide sequence and gene expression leading to cell $\mathrm{Mg}^{2+}$ release and stable RNA degradation. Biochim Biopbys Acta 1007, 158-166.

Stewart, G. S. A. B., Lubinsky-Mink, S., Jackson, C. G., Cassel, A. \& Kuhn, J. (1986). pHG165: a pBR328 copy number derivative of pUC8 for cloning and expression. Plasmid 15, 172-181.

Wilkins, B. M. (1995). Gene transfer by bacterial conjugation: diversity of systems and functional specializations. In Population Genetics of Bacteria, Society for General Microbiology Symposium 52, pp. 59-88. Edited by S. Baumberg, J. P. W. Young, E. M. H. Wellington \& J. R. Saunders. Cambridge: Cambridge University Press.

Wilson, G. G. \& Murray, N. E. (1991). Restriction and modification systems. Annu Rev Genet 25, 585-627.

Yanisch-Perron, C., Vieira, J. \& Messing, J. (1985). Improved M13 phage cloning vectors and host strains: nucleotide sequences of the M13mp18 and pUC19 vectors. Gene 33, 103-119.

Received 10 April 1995; revised 22 May 1995; accepted 31 May 1995. 